\title{
Synthesis, Characterization and Pharmacological Evaluation of Amide Prodrugs of Flurbiprofen
}

\author{
Ashutosh Mishra, Ravichandran Veerasamy, Prateek Kumar Jain, \\ Vinod Kumar Dixit and Ram Kishor Agrawal*
}

\author{
Pharmaceutical Chemistry Research Laboratory, Department of Pharmaceutical Sciences, \\ Dr. H. S. Gour Vishwavidyalaya, Sagar (M.P) - 470 003, India
}

O flurbiprofen (FB) apresenta efeitos colaterais comuns às drogas do tipo NSAIDs (Nonsteroidal anti-inflammatory drugs - drogas não esteróides anti-inflamatórias), devido à presença do grupo carboxílico livre. O objetivo desse estudo foi retardar esses efeitos adversos de origem gastrointestinal. Dez pró-fármacos derivados do FB foram sintetizados por amidação com ésteres etílicos de amino-ácidos, a saber: glicina, L-fenilanilina, L-triptofan, L-valina, L-isoleucina, L-ácido glutâmico, L-ácido aspártico e $\beta$ alanina. Os pró-fármacos sintetizados e purificados foram caracterizados por m.p., TLC, solubilidade, coeficientes de partição, análise elementar, UV, FTIR, NMR e MS. Foram submetidos também a estudos de biodisponibilidade, à atividade analgésica e anti-inflamatória e ao índice ulcerogênico. Os resultados obtidos mostraram redução acentuada do índice ulcerogênico e das atividades analgésica e anti-inflamatória comparáveis em todas os casos em relação ao FB. Os pró-fármacos sintetizados AR-9, AR-10 e AR-2 apresentaram uma excelente resposta farmacológica e velocidade de hidrólise encorajadoura em ambos os testes com SIF (Simulated Intestinal Fluid) e com plama humano a $80 \%$. Os pró-fármacos com cadeia lateral aumentada ou com um substituinte aromático apresentam um melhor coeficiente de partição. Contudo, a solubilidade e a velocidade de hidrólise decresceram. Tais pró-fármacos podem ser considerados para uso com liberação sustentável.

Flurbiprofen (FB) suffers from the general side effects of NSAIDs, owing to presence of free carboxylic acid group. The study was aimed to retard the adverse effects of gastrointestinal origin. Ten prodrugs of FB were synthesized by amidation with ethyl esters of amino acids, namely, glycine, L-phenylalanine, L-tryptophan, L-valine, L-isoleucine, L-alanine, L-leucine, L-glutamic acid, L-aspartic acid and $\beta$ alanine. Purified synthesized prodrugs were characterized by m.p., TLC, solubility, partition coefficients, elemental analyses, UV, FTIR, NMR and MS. Synthesized prodrugs were subjected for bioavailibility studies, analgesic, anti-inflammatory activities and ulcerogenic index. Marked reduction of ulcerogenic index and comparable analgesic, antiinflammatory activities were obtained in all cases as compared to FB. Among synthesized prodrugs AR-9, AR-10 and AR-2 showing excellent pharmacological response and encouraging hydrolysis rate both in (Simulated Intestinal Fluid) SIF and in $80 \%$ human plasma. Prodrugs with increased aliphatic side chain length or introduction of aromatic substituent resulted in enhanced partition coefficient but diminished dissolution and hydrolysis rate. Such prodrugs can be considered for sustained release purpose.

Keywords: prodrugs, bioavailability, physical characterization, pharmacokinetics, pharmacodyanamics, flurbiprofen

*e-mail: dragrawal2001@yahoo.co.in 


\section{Introduction}

Flurbiprofen (FB), a non-steroidal anti-inflammatory drug, could not be used as to its' potentials because of adverse reactions offered due to presence of free carboxylic acid group. The non-steroidal anti-inflammatory drugs (NSAIDs) are widely used for indications extending from inflammation and pain to cardiovascular and genitourinary diseases. In the recent years a number of NSAIDs have been introduced into clinical practice. Hunt is on to relieve pain and inflammation with freedom of undesirable effects. Gastrointestinal side effects constitute the most frequent of all the adverse reactions of NSAIDs and often these reactions lead to GIT (Gastro Intestinal Tract) ulceration and hemorrhage. GI (Gastro intestine) mucosal injury produced by NSAIDs is generally believed to be causes by two different mechanisms. ${ }^{1}$ The first mechanism involves a local action comprised of a direct contact and second on indirect effect on the GI mucosa. The direct contact effect can be attributed to a combination of a local irritation produced by acidic group of NSAIDs and local inhibition of prostaglandin synthesis in the GIT. The indirect effect can be attributed to combination of an ion trapping mechanism of NSAIDs from the lumen into the mucosa. The second mechanism is based on a generalized systemic action occurring after absorption, which can be demonstrated following intravenous dosing. Recently, considerable attention has been focused in the development of bio-reversible derivatives, by temporarily masking the acidic group of NSAIDs, as a promising mean of reducing or abolishing the GI toxicity.

In the present study well-recognized NSAID, Flurbiprofen (FB) was selected, which suffers with the gastrointestinal side effects. Literature reveals that many efforts had been made to synthesize amino acid ester, glycolamide ester, and amide prodrugs using various amines but few attempts were made to develop amide prodrugs using amino acids. ${ }^{2-12}$ The salient features of the usefulness of conjugation of amino acids with NSAIDs are as follows: ${ }^{13}(i)$ Amino acids are normal dietary constituent and they are non-toxic in moderate doses as compared to other promoities; (ii) Amino acids have healing effect on gastric lesions produced by NSAIDs; (iii) A drug with free carboxyl group can be derivatized into corresponding esters or amide of amino acids, so as to alter the physical properties of a parent drug with one or more of the hydrolase enzymes serving as the in-vivo reconversion site(s); (iv) Being a nutritional substance, the use of amino acids as a derivatizing group might also permit more specific targeting site for enzymes involved in the terminal phase of digestion; ( $v$ ) Many amino acids possess marked anti-inflammatory activity against gelatin induced hind paw oedema in rats; (vi) By using different types of amino acids like non-polar, polar, acidic and basic, the drug molecule can be made more or less polar, or more or less soluble in given solvent. Thus present work aims to synthesize amide prodrugs of FB using amino acid ester with the expectation to get non-toxic prodrugs with minimized GIT disturbances while maintaining the useful anti-inflammatory and analgesic activities. Various proteolytic enzymes will help in release of FB by hydrolysis of peptide linkage. The list of synthesized prodrugs along with product codes, chemical names, possible trivial names and molecular structures is given as Table 1 .

\section{Experimental}

\section{Materials}

All the amino acids, namely, glycine, L-phenylalanine, L-tryptophan, L-valine, L-isoleucine, L-alanine, L-leucine, L-glutamic acid, L-aspartic acid and $\beta$-lanine were accquired from M/S Hi-Media Ltd., Mumbai. Drug FB was obtained as gift sample from M/S Knoll, Mumbai. Other reagents and solvent used were of Analytical/ spectroscopic/HPLC grade as the case desired. Bruker DRx300 1HNMR spectroscopy, Jeol SX102-FAB mass spectroscopy and Schimadzu 820 IPC IR spectrophotometer (CDRI, Lucknow, India), HPLC (Shimadzu liquid chromatograph-LC-10AT).

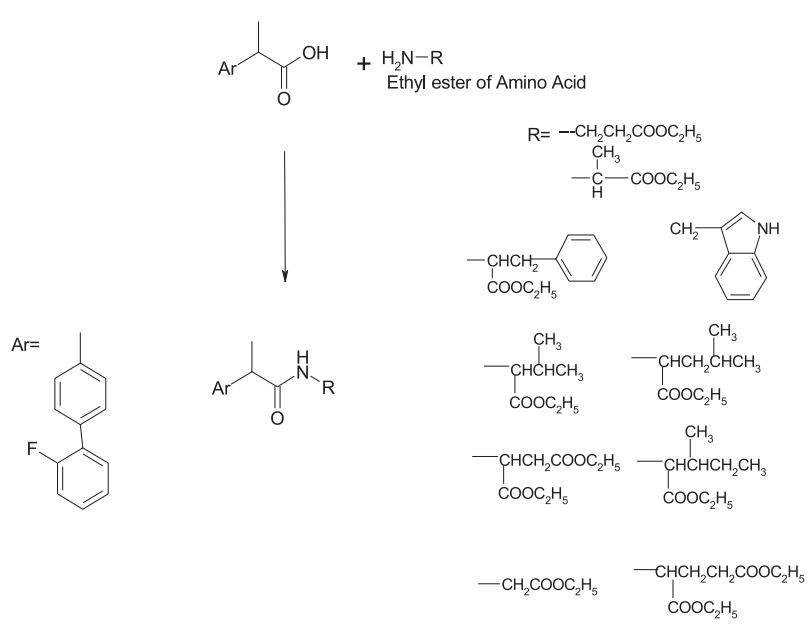

Figure 1. Scheme of syntheses.

Synthesis of ethyl esters of amino acid hydrochloride salts

Amino acid contains both acidic and basic groups in the same molecule and exists in the zwitterionic form. The nonavailability of the free amino group in the zwitterionic form of the amino acid restricts its use in the formation of amide. 
Table 1. List of synthesized prodrugs of flurbiprofen

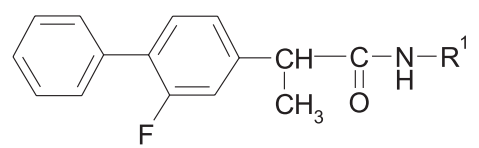

\begin{tabular}{ll}
\hline Code & Chemical Name \\
\hline AR-1 & RS-2-[(2'-fluorobiphenyl-4'yl)-N-ethylacetate $)]$ propionamide \\
AR-2 & RS-2-[(2'-fluorobiphenyl-4'yl)-N-(2-ethylpropionate $)]$ propionamide \\
AR-3 & RS-2-[2'-fluorobiphenyl-4'yl)-N-(3-ethylpropionate) $]$ prpionamide \\
AR-4 & RS-2-[(2'-fluorobiphenyl-4'yl)-N-(2-(3-(3-benzimidazole))ethylpropionate) $]$ propionamide
\end{tabular}

AR-5 RS-2-[(2'-fluorobiphenyl-4'yl)-N-(2-(3-phenyl)ethyl propionate)] propionamide

AR-6 RS-2-[(2'-fluorobiphenyl-4'yl)-N-(2-(3-methyl)ethyl butyrate)] propionamide

AR-7 RS-2-[(2'-fluorobiphenyl-4'yl-)-N- (2-(4-methyl)ethyl pentoate] propionamide

AR-8 RS-2-[(2'-fluorobiphenyl-4'yl-)-N-(2-(3-methyl)ethyl pentoate)] propionamide

$\mathrm{R}^{1}$

$-\mathrm{CH}_{2} \mathrm{COOC}_{2} \mathrm{H}_{5}$
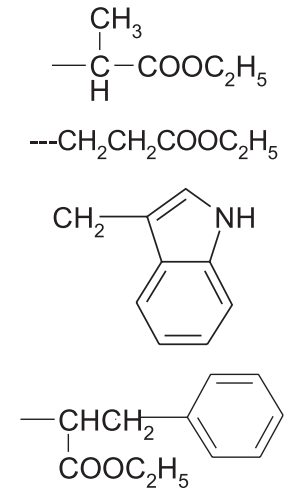

$\mathrm{CH}_{3}$<smiles>CCOC(=O)C(C)C</smiles><smiles>CCOC(=O)C(C)CC(C)C</smiles>

$\mathrm{CH}_{3}$<smiles>CCC(C)C(C)C(=O)OC</smiles><smiles>COC(=O)OCC1CCCC1CCCO</smiles>
$\mathrm{COOC}_{2} \mathrm{H}_{5}$ $-\mathrm{CHCH}_{2} \mathrm{CH}_{2} \mathrm{COOC}_{2} \mathrm{H}_{5}$ $\mathrm{COOC}_{2} \mathrm{H}_{5}$
Esterification of amino acid in presence of $\mathrm{HCl}$ produces amino acid ester hydrochloride in which neutralization of $\mathrm{HCl}$, using aqueous alkali, pyridine or triethylamine, generates free amino group to react as nucleophile in the synthesis of amide.

\section{Method 1}

Amino acid $\left(0.01 \mathrm{~mol} \mathrm{~L}^{-1}\right)$ in ethanolic hydrogen chloride $(100 \mathrm{~mL})$ was taken in a round bottom flask fixed with reflux condenser placed over a water bath and refluxed for $24 \mathrm{~h}$. After refluxing, evaporation of the solvent at reduced pressure gave crude ethyl ester hydrochloride. Crude product was dried in vacuum desiccator to get the solid product which was recrystallized by dissolving the product in minimum volume of absolute alcohol by slow addition of ether followed by cooling at $0{ }^{\circ} \mathrm{C}$. Recrystallized product was washed with anhydrous ether and dried under vacuum. This method was utilized for syntheses of ethyl ester hydrochloride salts of glycine, L-phenylalanine, L-leucine, $\beta$-alanine and L-valine.

\section{Method 2}

Amino acid $\left(0.025 \mathrm{~mol} \mathrm{~L}^{-1}\right)$, absolute alcohol $(400 \mathrm{~mL})$ and concentrated $\mathrm{HCl}$ were taken in a round bottom flask. The solvent was distilled off, at a very slow rate, at $70^{\circ} \mathrm{C}$. Dry toluene was added time to time in the reaction mix- 
ture to remove the water produced during the esterification reaction. After the complete removal of the alcohol a little more quantity of alcohol was further added along with dry toluene. After 4 - $6 \mathrm{~h}$, the remaining solvent was evaporated under high vacuum to get the crude ethyl ester hydrochloride of amino acid. Product was collected and dried. Recrystallisation was performed by dissolving the product in minimum quantity of warm alcohol followed by slow addition of anhydrous ether at $4^{\circ} \mathrm{C}$. Product was dried under vacuum and collected in airtight container. This method was utilized for synthesis of ethyl ester hydrochloride salts of L-aspartic acid.

\section{Method 3}

Amino acid $\left(0.01 \mathrm{~mol} \mathrm{~L}^{-1}\right)$ in ethanolic hydrogen chloride $(100 \mathrm{~mL})$ was taken in a round bottom flask and the reaction mixture was kept over a water bath, using a quick fit reflux condenser, for $24 \mathrm{~h}$. After refluxing, evaporation of the solvent at reduced pressure gave crude ethyl ester hydrochloride. Crude product was dried in vacuum desiccator to get the solid product, which was recrystallized by dissolving the product in minimum volume of absolute alcohol by slow addition of ether followed by cooling at $0^{\circ} \mathrm{C}$. Recrystallized product was washed with anhydrous ether and dried under high vacuum. This method was utilized for syntheses of ethyl ester hydrochloride salts of L-tryptophan, L-isoleucine and L-alanine.

\section{General procedure for acylation of amino acid ethyl ester hydrochloride}

Acylation of amino acid ethyl ester hydrochloride was done by six methods using acid anhydride of FB, acid chloride of FB and triethylamine as base, acid chloride of FB and potassium carbonate as base, acid chloride of FB and pyridine as base, DCC, drug (1:1) and triethylamine as base and acid anhydride of FB and triethylamine as base

\section{Method 1}

Amino acid ester hydrochloride $\left(0.5 \mathrm{~mol} \mathrm{~L}^{-1}\right)$ and triethyl amine $(2 \mathrm{~mL})$ were dissolved in $10 \mathrm{~mL}$ of methylene chloride and stirred mechanically for $10 \mathrm{~min}$ to neutralize the ester hydrochloride. This solution was added slowly to the freshly synthesized acid anhydride of flurbiprofen in methylene chloride at $0{ }^{\circ} \mathrm{C}$ for $30 \mathrm{~min}$, followed by stirring at room temperature for $24 \mathrm{~h}$. The solvent was removed at reduced pressure, $10 \mathrm{~mL}$ ethyl acetate was further added to the dried product and filtered to remove the triethylamine hydrochloride. The filtrate was washed three times with $10 \%$ aqueous sodium bicarbonate solution and three times with water and dried over anhydrous magnesium sulphate and the solvent was removed under reduced pressure. White amorphous mass was obtained, which was dried under vacuum. Crude material was dissolved in minimum amount of alcohol, followed by the slow addition of distilled water until further precipitation stopped. After filtration it was dried in air to get a solid product. This method was used to synthesize product AR-9 and AR-10.

\section{Method 2}

Amino acid ester hydrochloride $\left(0.1 \mathrm{~mol} \mathrm{~L}^{-1}\right)$ and triethylamine $(2 \mathrm{~mL})$ was added in $20 \mathrm{~mL}$ dry chloroform and stirred for $1 \mathrm{~h}$ to neutralize ester hydrochloride. To this solution, acid chloride of FB in dry chloroform was added slowly in dropwise manner at $0^{\circ} \mathrm{C}$ for $30 \mathrm{~min}$ followed by stirring at room temperature for $30 \mathrm{~h}$ and then the solvent was evaporated under reduced pressure. Crude product was dissolved in $10 \mathrm{~mL}$ ethyl acetate and washed three times with $10 \%$ aqueous sodium bicarbonate solution and with distilled water to remove the traces of unreacted FB and alkali. Finally it was dried over anhydrous magnesium sulphate for whole night. The solution was filtered and the solvent was removed under reduced pressure to get the crude product. It was re-crystallized using alcohol-water mixture. Recrystallized product was filtered off, dried in air and stored in airtight container. This method was used to synthesize product AR-4.

\section{Method 3}

Amino acid ester hydrochloride $\left(0.01 \mathrm{~mol} \mathrm{~L}^{-1}\right)$ was taken in $5 \%$ aqueous solution of potassium carbonate at $2-5^{\circ} \mathrm{C}$, followed by dropwise addition of solution of acid chloride of FB in chloroform. Reaction mixture was stirred for $3 \mathrm{~h}$ at the same temperature. White precipitate was obtained and it was removed, and then washed with distilled water. Product was dried in vacuum and recrystallised by selective precipitation using alcohol-water mixture. It was dried in air and stored in tightly closed container. This method was used to synthesize product AR-1, AR-2 and AR-7.

\section{Method 4}

Amino acid hydrochloride $\left(0.01 \mathrm{~mol} \mathrm{~L}^{-1}\right)$ was taken in pyridine at room temperature. To this solution, freshly prepared acid chloride of FB $\left(0.01 \mathrm{~mol} \mathrm{~L}^{-1}\right)$ in dry toluene was added slowly in dropwise manner. The reaction mixture was stirred for $24 \mathrm{~h}$ at room temperature. After completion of the reaction, pyridine was distilled off to get a gel like mass containing product along with traces of pyridine. Crushed ice was added repeatedly to dissolve the remaining pyridine. Product was removed by filtration and dried in vacuum. Recrystallisation was performed by selective precipitation using alcohol-water mixture. Recrystallized product was dried and stored at cold condition in tightly 
closed container. This method was used to synthesize product AR-3.

\section{Method 5}

FB (0.1 mol $\left.\mathrm{L}^{-1}\right)$ was dissolved in $40 \mathrm{~mL}$ methylene chloride followed by addition of DCC $\left(0.1 \mathrm{~mol} \mathrm{~L}^{-1}\right)$. Reaction mixture was stirred for $30 \mathrm{~min}$. To this solution was added a mixture of amino acid hydrochloride $\left(0.1 \mathrm{~mol} \mathrm{~L}^{-1}\right)$ and trietylamine $(2 \mathrm{~mL})$ in $20 \mathrm{~mL}$ of methylene chloride in dropwise manner. Reaction mixture was stirred at $0{ }^{\circ} \mathrm{C}$ initially for $2 \mathrm{~h}$ followed by stirring at room temperature for overnight. Precipitated DHU was filtered off and the solvent was removed at reduced pressure. Ethyl acetate $(10 \mathrm{~mL})$ was added to the dried product to remove the remaining DHU. Ethyl acetate layer was washed with $10 \%$ aqueous solution of sodium bicarbonate and distilled water to remove the triethylamine hydrochloride and traces of alkali. Ethyl acetate layer was dried over anhydrous magnesium sulphate and filtered off and the solvent was removed at reduced pressure to get the crude product. Product was recrystallized by selective precipitation using alcohol-water mixture, dried and stored in cold condition in tightly closed container. This method was used to synthesize product AR-5 and AR-6.

\section{Method 6}

Amino acid hydrochloride $\left(0.1 \mathrm{~mol} \mathrm{~L}^{-1}\right)$, triethylamine ( $2 \mathrm{~mL})$ and FB $\left(0.2 \mathrm{~mol} \mathrm{~L}^{-1}\right)$ was dissolved in $40 \mathrm{~mL}$ of methylene chloride. The reaction mixture was stirred at $0^{\circ} \mathrm{C}$ for $30 \mathrm{~min}$. To this solution was added DCC $(0.1 \mathrm{~mol}$ $\left.\mathrm{L}^{-1}\right)$ in $10 \mathrm{~mL}$ of methylene chloride slowly in a dropwise manner. Reaction mixture was stirred for $24 \mathrm{~h}$. Precipitated DHU was filtered off and the solvent was distilled off under reduced pressure. Product thus obtained was again dissolved in $10 \mathrm{~mL}$ of ethyl acetate and filter. Filtrate was washed with $10 \%$ aqueous solution of sodium bicarbonate and distilled water in order to remove unreacted FB, triethylamine hydrochloride and traces of alkali present. Ethyl acetate layer was dried over anhydrous magnesium sulphate and filtered to get a clear solution of product in ethyl acetate. Solvent was evaporated under reduced pressure and the crude product was recrystallized by dissolving it in ethyl alcohol followed by the addition of water until further precipitation stopped. Product was filtered, dried and stored in tightly closed container in cold condition. This method was used to synthesize product AR-8.

\section{Characterization of the synthesized prodrugs}

The synthesized compounds were subjected to thin layer chromatography in order to check their purity. The prepared plates of silica gel $\mathrm{G}$ adsorbents were dried and activated. The solvent system methanol:acetic acid:ether:benzene, 1:18:60:20 was used for FB. Iodine vapour was used as detecting agent. All compounds gave single spot. The melting points of the synthesized prodrugs were determined by open capillary tube using Toshniwal melting point apparatus and are uncorrected. The IR spectra of the compounds were obtained on IR spectrophotometer (Schimadzu 820 IPC) in KBr phase. The ${ }^{1}$ HNMR spectral analysis of the synthesized prodrugs was done on NMR spectrophotometer (Bruker DRx300) using $\mathrm{CDCl}_{3}$ as solvent. The mass was determined on FAB mass spectrometer (Jeol SX102-FAB) (CDRI, Lucknow, India).

\section{Partition coefficient}

$20 \mathrm{mg}$ of prodrug was weighed and dissolved in $20 \mathrm{~mL}$ chloroform. This solution was divided in two parts and in each part was added $10 \mathrm{~mL}$ acidic buffer ( $\mathrm{pH}$ 1.2) and phosphate buffer ( $\mathrm{pH}$ 7.4) separately. The contents were thoroughly shaken for $24 \mathrm{~h}$ at room temperature followed by transferring in separating funnel. The chloroform layer was dried under high vacuum and the residue obtained was again dissolved in methanol $(10 \mathrm{~mL})$. A $0.020 \mathrm{~mL}$ of this solution was further diluted to $1 \mathrm{~mL}$ with methanol. From this solution an aliquot of $0.250 \mathrm{~mL}$ was withdrawn and was mixed with $0.045 \mathrm{~mL}$ solution of acidic buffer $(\mathrm{pH} 1.2)$ or phosphate buffer ( $\mathrm{pH} 7.4$ ) and acetonitrile in 44:1. Volume was finally made to $1 \mathrm{~mL}$ by addition of methanol. A $0.020 \mathrm{~mL}$ of this solution was filtered and injected into HPLC column $\left(\mathrm{C}_{18}\right)$. The mobile phase's acetonitrile: water 70:30 ( $\mathrm{pH}$ adjusted to 2.9 using acetic acid) and acetonitrile: water 50:50 was used for FB prodrugs. The peak area for drug as well as prodrug was observed at $247 \mathrm{~nm}$ using UV detector (DAD, SPD-M10A with D2 lamp).

\section{Biopharmaceutical evaluations}

\section{Plasma protein binding studies}

A solution of synthesized prodrug $(20 \mu \mathrm{g} \mathrm{mL}-1)$ was made in phosphate buffered saline (PBS, pH 7.4). A $100 \mathrm{~mL}$ of this solution was taken in a beaker. The prepared membrane was first washed with distilled water and then with buffer solution (pH7.4). It was tied at the opening end of dialysis tube, the dialysis tube containing (6\%) egg albumin was dipped into the drug solution and covered. The whole assembly was placed on a magnetic stirrer and switched at low rpm. The temperature was maintained at $37 \pm 0.5^{\circ} \mathrm{C}$. After every two hours, $1 \mathrm{~mL}$ of the PBS containing drug solution was replaced of the beaker with fresh $1 \mathrm{~mL}$ of PBS. Withdrawn sample was diluted further with $1 \mathrm{~mL}$ phosphate buffer and the concentration 
of the prodrug was estimated spectrophotometrically using spectrophotometer (Shimadzu-1601).

\section{Dissolution rate studies ${ }^{14}$}

Dissolution test apparatus (USPXXI) was adjusted to 100 rpm speed and $37 \pm 0.5^{\circ} \mathrm{C}$ temperature. Prodrug $(10 \mathrm{mg})$ was suspended in $2 \mathrm{~mL}$ simulated gastric fluid (SGF, $\mathrm{pH}$ 1.2), in a dialysis bag (Cut off size 5000) kept inside the basket. The basket was dipped in simulated gastric fluid (SGF) (900 $\mathrm{mL}$ ), which was kept in the internal jar of the dissolution test apparatus. Five $\mathrm{mL}$ samples were withdrawn after every 10 min and the volume was replaced by fresh simulated gastric fluid every time. Samples withdrawn from dissolution test apparatus were subjected to HPLC. The measurement of peak area of the prodrugs was noted at $247 \mathrm{~nm}$ using UV detector for FB and prodrugs.

The samples of synthesized prodrugs as well as drug from the dissolution study in SGF did not show their presence up to $2 \mathrm{~h}$, which is considered as maximum time for any drug that remains in stomach, so after $2 \mathrm{~h}$. SGF was replaced by simulated intestinal fluid (SIF) $(900 \mathrm{~mL})$ and the dissolution test was run again, under similar conditions of temperature and speed.

The same procedure was followed for all synthesized prodrugs. Dissolution profiles of synthesized prodrugs are compiled and shown in Figure 2.

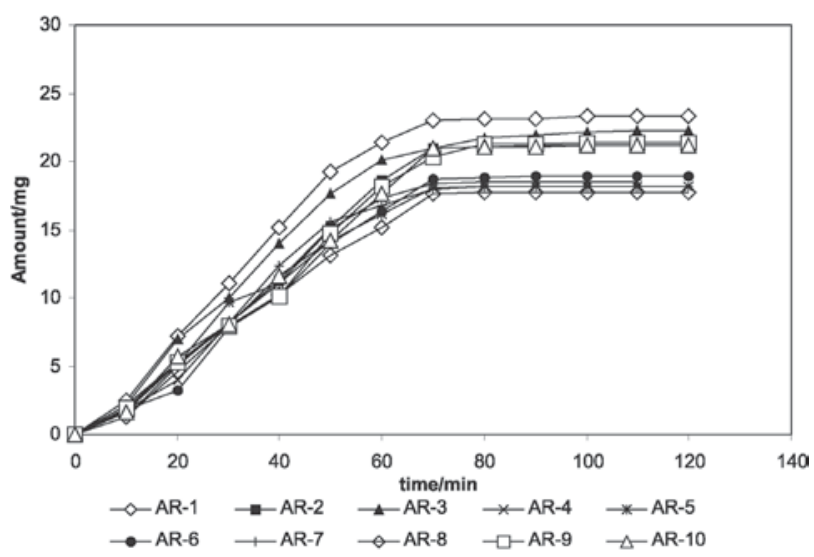

Figure 2. Dissolution profile of amide prodrugs of flurbiprofen.

Studies on hydrolytic behavior of synthesized prodrugs

Hydrolytic behavior of synthesized prodrugs was studied in SGF (pH 1.2; USP 1970); SIF (pH 7.4; USP 1970) and $80 \%$ human plasma. The method adopted for the studies is as following:

Method for the determination of hydrolysis rate in SGF and SIF

A solution of $10 \mathrm{mg}$ of prodrug was prepared in ac- etonitrile $(2 \mathrm{~mL})$ and was added to the $88 \mathrm{~mL}$ of SIF (pH 7.4) or SGF (pH 1.2). An aliquot of $15 \mathrm{~mL}$ of this solution was withdrawn at definite interval of $15 \mathrm{~min}$ and was kept in test tubes maintained at $37 \pm 0.5^{\circ} \mathrm{C}$. An aliquot of $0.225 \mathrm{~mL}$ was withdrawn from different test tubes and was transferred to microcentrifuge tubes (Eppendrof"s tube) followed by the addition of methanol to make up the volume. The tubes were placed in freezing mixture in order to arrest further hydrolysis, followed by vortexing at high speed for $5 \mathrm{~min}$. After vortexing, the tubes were centrifuged at high speed (3000 rpm) for $5 \mathrm{~min}$. Clear supernatant $(0.020 \mathrm{~mL})$ obtained from each tube was subjected for HPLC analysis using $\mathrm{C}_{18}$ column and mobile phase acetonitrile : water 70 : 30 ( $\mathrm{pH} 2.3$ adjusted with acetic acid ). Flow rate of mobile phase was kept at $1 \mathrm{~mL} / \mathrm{min}$ at pressure $120-135$ psi and UV detector (DAD-SPD-M10A with $\mathrm{D}_{2}$ lamp) was used and retention time and peak area were noted at $247 \mathrm{~nm}$. The comparative study of rate of hydrolysis is shown in Figure 3.

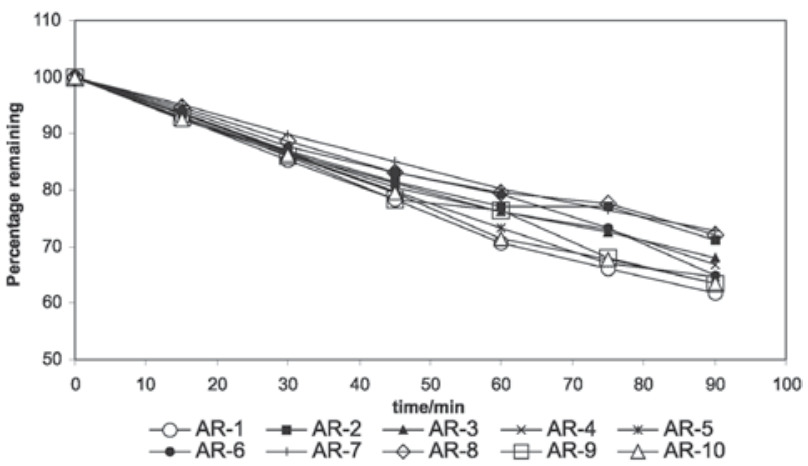

Figure 3. In vitro hydrolytic pattern of amide prodrugs of flurbiprofen in simulated intestinal fluid $\mathrm{pH} 7.4$..

Method for the hydrolysis rate determination of prodrugs in $80 \%$ human plasma ( $\mathrm{pH} 7.4$ )

A solution of $10 \mathrm{mg}$ of prodrug was prepared in acetonitrile $(2 \mathrm{~mL})$ and was added to the $88 \mathrm{~mL}$ of $80 \%$ human plasma ( $\mathrm{pH} 7.4$ ), (prepared by mixing 80 portion of plasma with 20 portion of phosphate buffer- $\mathrm{pH}$ 7.4). An aliquot of $15 \mathrm{~mL}$ of this solution was withdrawn and kept in test tubes maintained at $37 \pm 0.5^{\circ} \mathrm{C}$. An aliquot of $0.225 \mathrm{~mL}$ was withdrawn from different tubes at interval $15 \mathrm{~min}$ and was transferred to microcentrifuge tubes. Then the solution was treated as above mentioned procedure. The comparative study of rate of hydrolysis is shown in Figure 4.

\section{Pharmacological evaluations}

All the synthesized prodrugs along with FB were evaluated for analgesic, anti-inflammatory activities and ulcerogenic index. The prodrugs were compared with FB 


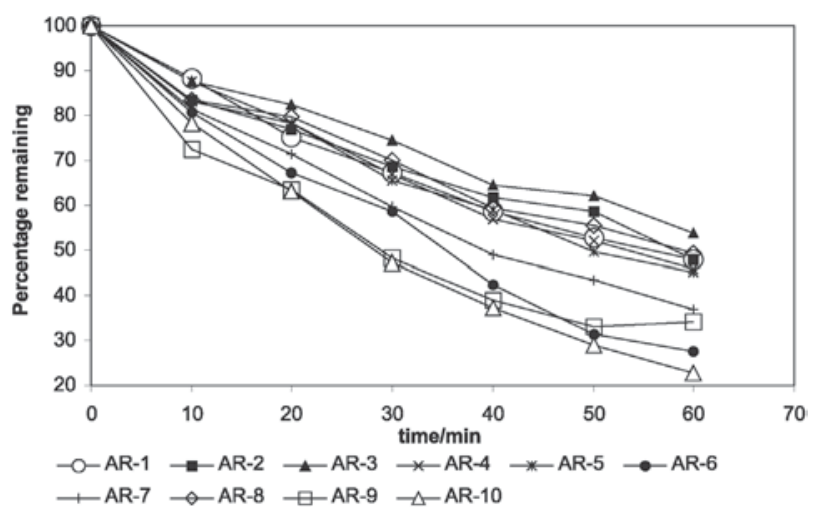

Figure 4. In vitro hydrolytic pattern of amide prodrugs of flurbiprofen in $80 \%$ human plasma $\mathrm{pH} 7.4$.

for these activities. The methods employed for this purpose were as following:

\section{Anti-inflammatory activity}

Anti-inflammatory activity of synthesized prodrugs was determined by hind paw oedema method utilizing carrageenan $(0.1 \mathrm{~mL}, 1 \%)$ as phlogistic agent. Carragenan produces inflammation and oedema by causing the release of histamine, 5-HT and bradykynin. The animals used were Wistar rats (albino rats). Rats (100-200 g) (we want to find out the prodrug effect in younger rats also, so we have chosen the weight of rats between 100-200 g) were divided into seven groups, each comprising of 3 rats, including a control and standard group. The initial volume of right hind paw of albino rats was measured by plethysomometer, without administration of the drug/ prodrug. The drug/ prodrugs (dose of each prodrug was calculated equivalent to $1.2 \mathrm{mg} \mathrm{kg}-1$ body weight) were administered orally in $1 \%$ suspension of sodium carboxymethylcellulose (containing $0.1 \% \mathrm{~m} / \mathrm{v}$ of drug or prodrug). After $30 \mathrm{~min}$ of administration of drug/ prodrugs, carrageenan $(0.1 \mathrm{~mL}, 1 \% \mathrm{~m} / \mathrm{v}$ solution in normal saline) was injected into the planter surface of right hind paw of each animal as phlogistic agent. The volume of right hind paw of albino rats was measured by plethysomometer after 3, 4 and $6 \mathrm{~h}$. The mean difference in the volume of the right hind paw of rats was compared with standard and control. Percent anti-inflammatory activity was calculated using the following formula:

anti-inflammatory activity $\%=\left[1-\left(\mathrm{V}_{\mathrm{t}}-\mathrm{V}_{\mathrm{c}}\right)\right] \times 100$

where $\mathrm{V}_{\mathrm{c}}=$ Mean relative change of the volume of the right hind paw of rats in the control group; $\mathrm{V}_{\mathrm{t}}=$ Mean relative change of the volume of the right hind paw of rats in the test group.

The comparative results are shown in Figure 5.

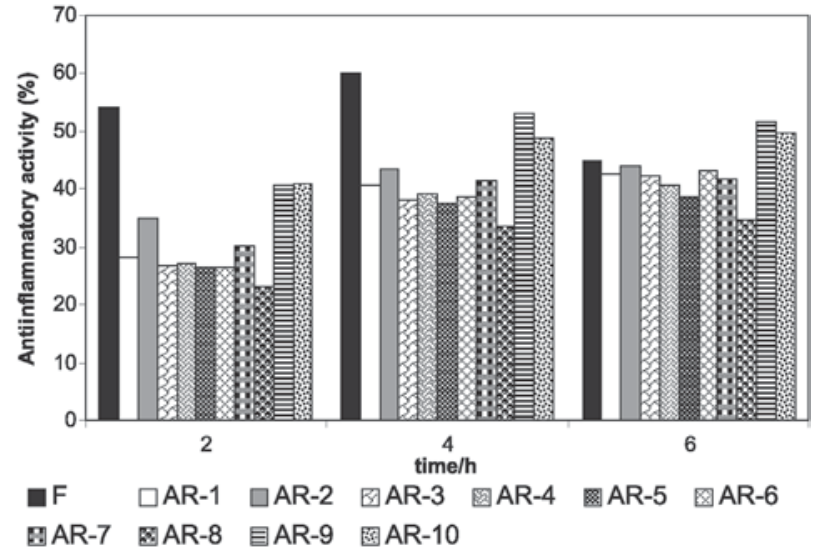

Figure 5. Comparative anti-inflammatory activities of amide prodrugs of flurbiprofen.

\section{Analgesic activity}

Analgesic activity of the synthesized prodrugs was determined by tail flick method using thermal stimulus. A hot water analgesiometer was used for the determination of pain threshold of Wistar rats (albino rats). Cold water was circulated through the water jackets of the instrument to avoid the heating of the area around the hot wire. Rats (100-200 g) were divided into seven groups, each comprising of 3 rats. The rat was placed in a holder through which the tail of the rat was protruded out. The normal reaction time, i.e., the time taken to flick the tail was noted. The current was adjusted so that more than $90 \%$ rats flick the tail within range of 5-9 sec. Animals showing delayed response were rejected. The drug/ prodrug (dose of each prodrug was calculated to equivalent to $1.2 \mathrm{mg} \mathrm{kg}^{-1}$ body weight) was administered orally in $1 \%$ suspension of sodium carboxymethylcellulose. Percent analgesia was calculated using the following formula

Analgesia $\%=\left[1-\left(\mathrm{T}_{2} / \mathrm{T}_{1}\right)\right] \times 100$

where $\mathrm{T}_{1}=$ reaction time in sec. before administration of drug/ prodrug; $\mathrm{T}_{2}=$ reaction time in sec. after administration of drug/ prodrug.

The results are shown in Figure 6.

\section{Ulcerogenic index}

Gastro-intestinal toxicity of the synthesized prodrugs was measured and compared with the drug by measuring ulcerogenic index. For this purpose male albino rats (Wistar rats) were selected, weighing between 130-150 g. The rats were divided into 23 groups each comprising of 3 rats, including a control and standard group. The prodrug/ drug $(100 \mathrm{mg}$ ) was suspended in $100 \mathrm{~mL}$ of $2 \% \mathrm{~m} / \mathrm{v}$ suspension of acacia. Measured volume of the suspension containing 


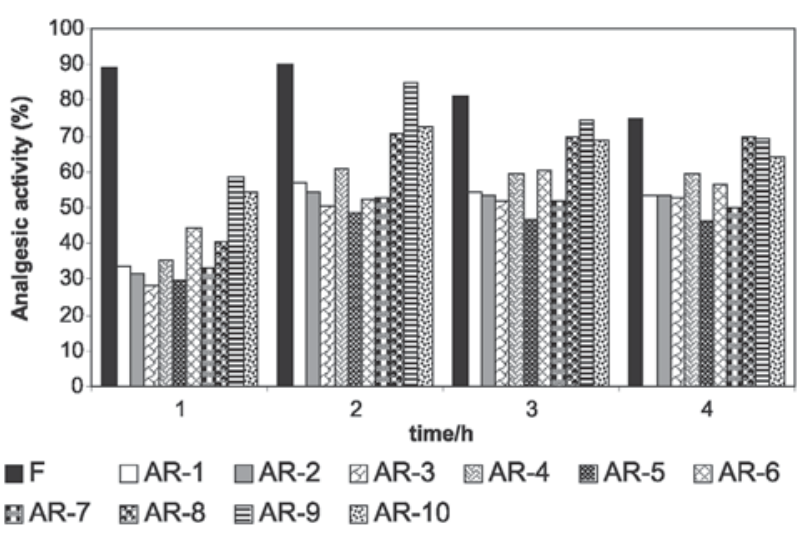

Figure 6. Comparative analgesic activity of amide prodrugs of flurbiprofen.

dose equivalent to $1.2 \mathrm{mg} \mathrm{kg-1}$ of body weight of $\mathrm{FB}$ was administered orally to the test group daily for five days. The rats were fasted after the administration of last dose, thereafter they were sacrificed by decapitation and the stomach was removed, opened and washed with distilled water. The lesions on the gastric mucosa were counted by visual examination using a $2 \times 2$ binocular magnifier. Ulcers greater than $0.5 \mathrm{~mm}$ were recorded.

\section{Results and Discussion}

Purity of synthesized prodrugs was ascertained by TLC using silica gel $\mathrm{G}$ and physical properties are shown in Table 2. Estimation of percentage nitrogen was in confirmation of desired structure. Calculated and found values of $\% \mathrm{Ni}$ trogen is clubbed with physical properties and is shown in Table 2. Characteristic absorption peaks obtained in FTIR, MS and NMR are reported in Table 3. Partition coefficient of FB and its prodrugs are shown in Table 4.
Acylation of amino acid ester was performed using various conditions like in the presence of $5 \% \mathrm{~K}_{2} \mathrm{CO}_{3}$ at $0-2^{\circ} \mathrm{C}$, non-aqueous acylation reaction in presence of pyridine, triethylamine and acylation reaction in presence of excess pyridine. All these methods suffer with the drawback of hydrolysis of acid chloride, slow rate of reaction and difficulty in the collection of final product; due to lump formation. The acylation of amino acid ester using anhydride (formed by reaction of drug with DCC in $2: 1$ ratio) suffered with the problem of poor yield. When equimolar drug and DCC were used, it gave satisfactory results. Recrystallisation of the compounds was performed by selective precipitation with water-alcohol mixture. In some cases the oily products were obtained which were crystallized by induced crystallization using n-hexane and/ or petroleum ether in the ethanolic solution of the prodrug. The synthesized prodrugs of FB were subjected to solubility, partition coefficient, dissolution and hydrolytic studies. Solubility studies showed that only FB was found highly soluble in $0.1 \mathrm{~N} \mathrm{NaOH}$. On contrary every synthesized prodrug was found slightly soluble in $0.1 \mathrm{~N} \mathrm{NaOH}$. The drug and all prodrugs were found insoluble in water and in $0.1 \mathrm{~N} \mathrm{HCl}$. But they showed moderate to high solubility in various solvents such as methanol, ethanol, chloroform, dichloromethane and benzene. The greater solubility of the standard drugs FB may be due to presence of free carboxyl group, which forms sodium salt and make the compound ionic. But all prodrugs and standard drug showed moderate to high solubility in various organic solvents, which indicate lipophilic behaviour of the compounds.

The partition coefficient studies at $\mathrm{pH} 7.4$ of the drug and FB prodrugs were found to be 1.847 . The $\mathrm{K}$ value of prodrugs of FB AR-1, AR-2, AR-3, AR-9 and AR-10 were found 23 to 29; K value of AR-6 and AR-4

Table 2. Physical constants of synthesized prodrugs of flurbiprofen

\begin{tabular}{|c|c|c|c|c|c|c|c|}
\hline \multirow{2}{*}{ Prodrug code } & \multirow{2}{*}{$\begin{array}{l}\text { Mecular } \\
\text { formula }\end{array}$} & \multirow{2}{*}{ MW calculated } & \multirow{2}{*}{$\mathrm{mp} /{ }^{\circ} \mathrm{C}$} & \multirow{2}{*}{$\%$ Yield } & \multirow{2}{*}{$\mathrm{R}_{\mathrm{f}}$ Value* $^{*}$} & \multicolumn{2}{|c|}{ Percentage Nitrogen } \\
\hline & & & & & & Found & Calc. \\
\hline AR-1 & $\mathrm{C}_{19} \mathrm{H}_{20} \mathrm{NO}_{3} \mathrm{~F}$ & 329 & $104-105$ & 72 & 0.59 & 4.19 & 4.25 \\
\hline AR-2 & $\mathrm{C}_{20} \mathrm{H}_{22} \mathrm{NO}_{3} \mathrm{~F}$ & 343 & $84-86$ & 80 & 0.63 & 3.52 & 3.34 \\
\hline AR-3 & $\mathrm{C}_{20} \mathrm{H}_{22} \mathrm{NO}_{3} \mathrm{~F}$ & 343 & $74-76$ & 52 & 0.66 & 4.04 & 4.08 \\
\hline AR-4 & $\mathrm{C}_{29} \mathrm{H}_{27} \mathrm{NO}_{3} \mathrm{~F}$ & 444 & $106-108$ & 62 & 0.77 & 3.11 & 3.15 \\
\hline AR-5 & $\mathrm{C}_{26} \mathrm{H}_{26} \mathrm{NO}_{3} \mathrm{~F}$ & 419 & $81-82$ & 81 & 0.81 & 3.39 & 3.34 \\
\hline AR-6 & $\mathrm{C}_{22} \mathrm{H}_{26} \mathrm{NO}_{3} \mathrm{~F}$ & 371 & $80-82$ & 64 & 0.74 & 3.72 & 3.77 \\
\hline AR-7 & $\mathrm{C}_{23} \mathrm{H}_{28} \mathrm{NO}_{3} \mathrm{~F}$ & 385 & $78-80$ & 66 & 0.83 & 3.59 & 3.63 \\
\hline AR-8 & $\mathrm{C}_{23} \mathrm{H}_{28} \mathrm{NO}_{3} \mathrm{~F}$ & 385 & $96-98$ & 57 & 0.82 & 3.59 & 3.63 \\
\hline AR-9 & $\mathrm{C}_{23} \mathrm{H}_{26} \mathrm{NO}_{5} \mathrm{~F}$ & 415 & $105-107$ & 52 & 0.68 & 3.31 & 3.37 \\
\hline AR-10 & $\mathrm{C}_{24} \mathrm{H}_{28} \mathrm{NO}_{5} \mathrm{~F}$ & 429 & $70-72$ & 71 & 0.69 & 3.24 & 3.26 \\
\hline
\end{tabular}

Melting points are uncorrected; * TLC (Adsorbent Silica Gel G, Solvent system Methanol: Acetic Acid: Ether: Benzene:: 1: 18: 60: 20). 
Table 3. IR, MS and $\mathrm{H}^{1}$ NMR spectral characterization of synthesized prodrugs of flurbiprofen

\begin{tabular}{|c|c|c|c|}
\hline $\begin{array}{l}\text { Prodrug } \\
\text { code }\end{array}$ & Characteristic peaks of IR spectra & Characteristic peaks of $\mathrm{H}^{1} \mathrm{NMR}$ spectra & $\begin{array}{l}\text { Mass } \\
(\mathrm{FAB}) \\
(\mathrm{M}+1)^{+}\end{array}$ \\
\hline AR-1 & $\begin{array}{l}3296(\mathrm{NH}), 3054 \text { (Ar CH), 2984, } 2938 \text { (Aliph CH), } 1746 \text { (C=O } \\
\text { str. of ester), } 1630 \text { (Amide I), } 1538 \text { (Amide II), 1376, } 1415(\mathrm{CH} \\
\text { bend, aliphatic), } 1207 \text { (C-O str. of ester). }\end{array}$ & $\begin{array}{l}8.0(\mathrm{br}, \mathrm{NH}), 7.3-7.1(\mathrm{~m}, 8 \mathrm{H} \text {, biphenyl ring }), 4.3\left(\mathrm{q}, 2 \mathrm{H}, \mathrm{OCH}_{2} \mathrm{CH}_{3}\right), 4.0(\mathrm{~m}, \\
\left.2 \mathrm{H}, \mathrm{CH}_{2} \mathrm{C}(=\mathrm{O}) \mathrm{OC}_{2} \mathrm{H}_{5}\right), 3.8\left(\mathrm{q}, 1 \mathrm{H}, \mathrm{CH}\left(\mathrm{CH}_{3}\right) \mathrm{C}(=\mathrm{O}) \mathrm{N}\right), 1.5\left(\mathrm{~d}, 3 \mathrm{H}, \mathrm{CH}\left(\mathrm{CH}_{3}\right)\right. \\
\mathrm{C}(=\mathrm{O}) \mathrm{N}), 1.3\left(\mathrm{t}, 3 \mathrm{H}, \mathrm{OCH}_{2} \mathrm{CH}_{3}\right) .\end{array}$ & 330 \\
\hline AR-2 & $\begin{array}{l}3296.8(\mathrm{NH}), 3050 \text { (Ar CH), 2968, 2724(Aliph CH), } 1738.4 \text { (C=O } \\
\text { str. of ester), } 1661 \text { (Amide I), 1576 (Amide II), 1392, } 1438 \text { (CH bend, } \\
\text { aliphatic), } 1161 \text { (C-O str. of ester). }\end{array}$ & $\begin{array}{l}8.0(\mathrm{br}, \mathrm{NH}), 7.3-7.1(\mathrm{~m}, 8 \mathrm{H}, \text { biphenyl ring }), 4.6\left(\mathrm{t}, 1 \mathrm{H}, \mathrm{CHCH}_{3}\right), 4.2\left(\mathrm{q}, 2 \mathrm{H}, \mathrm{OCH}_{2} \mathrm{CH}_{3}\right), \\
3.9\left(\mathrm{q}, 1 \mathrm{H}, \mathrm{CH}\left(\mathrm{CH}_{3}\right) \mathrm{C}(=\mathrm{O}) \mathrm{N}, 1.5\left(\mathrm{~d}, 3 \mathrm{H}, \mathrm{CH}_{3}\left(\mathrm{CH}_{3}\right) \mathrm{C}(=\mathrm{O}) \mathrm{N}\right), 1.4\left(\mathrm{~d}, 3 \mathrm{H}, \mathrm{CHCH}_{3}\right), 1.2(\mathrm{t},\right. \\
\left.3 \mathrm{H}, \mathrm{OCH}_{2} \mathrm{CH}_{3}\right) .\end{array}$ & 344 \\
\hline AR-3 & $\begin{array}{l}3312(\mathrm{NH}), 3018(\mathrm{Ar} \mathrm{CH}), 2954,2904 \text { (Aliph CH), } 1726(\mathrm{C}=\mathrm{O} \\
\text { str. of ester), } 1650 \text { (Amide I), } 1561 \text { Amide II), 1393, } 1446(\mathrm{CH} \\
\text { bend, aliphatic), } 1176 \text { (C-O str. of ester). }\end{array}$ & $\begin{array}{l}8.1(\mathrm{br}, \mathrm{NH}), 7.3-7.2(\mathrm{~m}, 8 \mathrm{H} \text {, biphenyl ring }), 4.3\left(\mathrm{q}, 2 \mathrm{H}, \mathrm{OCH}_{2} \mathrm{CH}_{3}\right), 3.9 \\
\left(\mathrm{q}, 1 \mathrm{H}, \mathrm{CH}\left(\mathrm{CH}_{3}\right) \mathrm{C}(=\mathrm{O}) \mathrm{N}, 1.5\left(\mathrm{~d}, 3 \mathrm{H}, \mathrm{CH}\left(\mathrm{CH}_{3}\right) \mathrm{C}(=\mathrm{O}) \mathrm{N}\right), 1.3(\mathrm{t}, 3 \mathrm{H},\right. \\
\left.\mathrm{OCH}_{2} \mathrm{CH}_{3}\right) .\end{array}$ & 344 \\
\hline AR-4 & $\begin{array}{l}3382(\mathrm{NH}), 3881.25(\mathrm{NH} \text { str of indole ring, } 3046(\mathrm{Ar} \mathrm{CH}), \\
2921,2859(\text { Aliph } \mathrm{CH}), 1738(\mathrm{C}=\mathrm{O} \text { str of ester), 1646(Amide } \\
\text { I), } 1553 \text { (Amide II), 1423, } 1384 \text { (CH bend, aliphatic), 1230(C-O } \\
\text { str of ester). }\end{array}$ & $\begin{array}{l}7.9(\mathrm{br}, \mathrm{NH}), 7.4-7.1(\mathrm{~m}, 8 \mathrm{H} \text {, biphenyl ring }), 6.8(\mathrm{~d}, 1 \mathrm{H}, \text { indole }), 4.7(\mathrm{~m}, \\
\left.1 \mathrm{H}, \mathrm{CHCH}_{2}\right), 4.3\left(\mathrm{q}, 2 \mathrm{H}, \mathrm{OCH}_{2} \mathrm{CH}_{3}\right), 3.8\left(\mathrm{q}, 1 \mathrm{H}, \mathrm{CH}\left(\mathrm{CH}_{3}\right) \mathrm{C}(=\mathrm{O}) \mathrm{N}, 3.0(\mathrm{~d},\right. \\
\left.2 \mathrm{H}, \mathrm{NH}-\mathrm{CHCH}_{2}\right), 1.6\left(\mathrm{~d}, 3 \mathrm{H}, \mathrm{CH}\left(\mathrm{CH}_{3}\right) \mathrm{C}(=\mathrm{O}) \mathrm{N}\right), 1.3\left(\mathrm{t}, 3 \mathrm{H}, \mathrm{OCH}_{2} \mathrm{CH}_{3}\right), \\
\text { ring). }\end{array}$ & 445 \\
\hline AR-5 & $\begin{array}{l}3312(\mathrm{NH}), 3062,3031 \text { (Ar CH), 2945, } 2851 \text { (Aliph CH str.), } \\
1746 \text { (C=O str. of ester), 1683(Amide I), 1569.1 Amide II), 1376, } \\
1433 \text { (CH bend, aliphatic), } 1230 \text { (C-O str. of ester). }\end{array}$ & $\begin{array}{l}8.0(\mathrm{br}, \mathrm{NH}), 7.3\left(\mathrm{~m}, 5 \mathrm{H}, \mathrm{CHCH}_{2} \mathrm{Ph}\right), 7.2-7.0(\mathrm{~m}, 8 \mathrm{H}, \text { biphenyl ring }), \\
4.8\left(\mathrm{~m}, 1 \mathrm{H}, \mathrm{CHCH}_{2} \mathrm{Ph}\right), 4.7\left(\mathrm{~d}, 2 \mathrm{H}, \mathrm{CHCH}_{2} \mathrm{Ph}\right), 4.3\left(\mathrm{q}, 2 \mathrm{H}, \mathrm{OCH}_{2} \mathrm{CH}_{3}\right), \\
3.8\left(\mathrm{q}, 1 \mathrm{H}, \mathrm{CH}\left(\mathrm{CH}_{3}\right) \mathrm{C}(=\mathrm{O}) \mathrm{N}, 1.6\left(\mathrm{~d}, 3 \mathrm{H}, \mathrm{CH}\left(\mathrm{CH}_{3}\right) \mathrm{C}(=\mathrm{O}) \mathrm{N}\right), 1.2(\mathrm{t}, 3 \mathrm{H},\right. \\
\left.\mathrm{OCH}_{2} \mathrm{CH}_{3}\right) .\end{array}$ & 420 \\
\hline AR-6 & $\begin{array}{l}3296(\mathrm{NH}), 3020(\mathrm{Ar} \mathrm{CH}), 2966,2931 \text { (Aliph CH), } 1735(\mathrm{C}=\mathrm{O} \\
\text { str. of ester), 1654, 1463, 1431, 1395, } 1372(\mathrm{CH} \text { bend, aliphatic), } \\
1270 \text { (C-O str. of ester). }\end{array}$ & $\begin{array}{l}8.1(\mathrm{br}, \mathrm{NH}), 7.3-7.1(\mathrm{~m}, 8 \mathrm{H}, \text { biphenyl ring }), 4.6\left(\mathrm{q}, 2 \mathrm{H}, \mathrm{OCH}_{2} \mathrm{CH}_{3}\right), 4.4(\mathrm{~m}, \\
1 \mathrm{H}, \mathrm{CH}-\mathrm{CH}\left(\mathrm{CH}_{3}\right), 3.7\left(\mathrm{q}, 1 \mathrm{H}, \mathrm{CH}\left(\mathrm{CH}_{3}\right) \mathrm{C}(=\mathrm{O}) \mathrm{N}, 3.1\left(\mathrm{~m}, 1 \mathrm{H}, \mathrm{CH}\left(\mathrm{CH}_{3}\right)_{2}, 1.6\right.\right. \\
\left(\mathrm{d}, 3 \mathrm{H}, \mathrm{CH}\left(\mathrm{CH}_{3}\right) \mathrm{C}(=\mathrm{O}) \mathrm{N}\right), 1.3\left(\mathrm{t}, 3 \mathrm{H}, \mathrm{OCH}_{2} \mathrm{~b}\right), 1.0\left(\mathrm{~d}, 6 \mathrm{H}, \mathrm{CH}\left(\mathrm{CH}_{3}\right)_{2} .\right.\end{array}$ & 372 \\
\hline AR-7 & $\begin{array}{l}3357(\mathrm{NH}), 3031(\mathrm{Ar} \mathrm{CH}), 2953,2906 \text { (Aliph CH str.), } \\
1730(\mathrm{C}=\mathrm{O} \text { str. of ester), 1661(Amide I), } 1605 \text { (Amide II), 1455, } \\
\text { 1416(CH bend, aliphatic), 1204(C-O str. of ester). }\end{array}$ & $\begin{array}{l}7.9(\mathrm{br}, \mathrm{NH}), 7.3-7.2(\mathrm{~m}, 8 \mathrm{H}, \text { biphenyl ring }), 4.5\left(\mathrm{~m}, 1 \mathrm{H}, \mathrm{CHCH}_{2}\right), 4.3(\mathrm{q}, \\
\left.2 \mathrm{H}, \mathrm{OCH}_{2} \mathrm{CH}_{3}\right), 3.8\left(\mathrm{q}, 1 \mathrm{H}, \mathrm{CH}\left(\mathrm{CH}_{3}\right) \mathrm{C}(=\mathrm{O}) \mathrm{N}, 1.8\left(\mathrm{~m}, 1 \mathrm{H}, \mathrm{CH}\left(\mathrm{CH}_{3}\right)_{2}\right),\right. \\
1.7\left(\mathrm{dd}, 2 \mathrm{H}, \mathrm{CHCH}_{2} \mathrm{CH}\left(\mathrm{CH}_{3}\right)_{2}\right), 1.6\left(\mathrm{~d}, 3 \mathrm{H}, \mathrm{CH}\left(\mathrm{CH}_{3}\right) \mathrm{C}(=\mathrm{O}) \mathrm{N}\right), 1.3(\mathrm{t}, 3 \mathrm{H}, \\
\left.\mathrm{OCH}_{2} \mathrm{CH}_{3}\right), 1.0\left(\mathrm{~d}, 6 \mathrm{H}, \mathrm{CH}\left(\mathrm{CH}_{3}\right)_{2}\right) .\end{array}$ & 386 \\
\hline AR-8 & $\begin{array}{l}\text { 3281(NH), } 3023 \text { (Ar CH), 2929, 2851(Aliph CH), } 1747 \text { (C=O } \\
\text { str. of ester), 1654(Amide I), } 1580 \text { (Amide II), 1448, 1384(CH } \\
\text { bend, aliphatic), 1221(C-O str. of ester). }\end{array}$ & 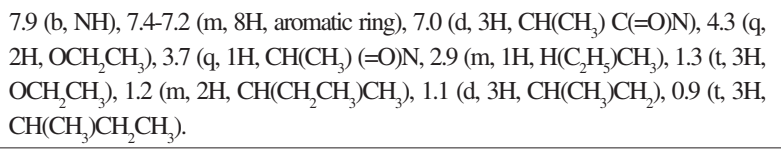 & 386 \\
\hline AR-9 & $\begin{array}{l}3333(\mathrm{NH}), 3037 \text { (Ar CH), 2984, } 2966 \text { (Aliph CH), } 1730 \text { (C=O } \\
\text { str. of ester), } 1646 \text { (Amide I), 1561(Amide II), 1415, } 1369(\mathrm{CH} \\
\text { bend, aliphatic), } 1184 \text { (C-O str. of ester). }\end{array}$ & 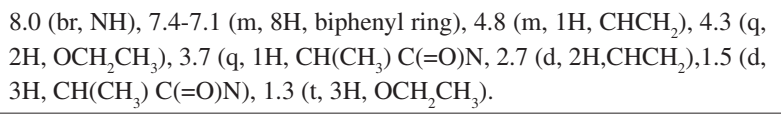 & 416 \\
\hline AR-10 & $\begin{array}{l}3312(\mathrm{NH}), 3046 \text { (Ar CH), 2953, } 2903 \text { (Aliph CH), } 1734 \text { (C=O } \\
\text { str. of ester), } 1656 \text { (Amide I), } 1549 \text { (Amide II), 1409, } 1363(\mathrm{CH} \\
\text { bend, aliphatic), } 1272 \text { (C-O str. of ester). }\end{array}$ & $\begin{array}{l}7.9(\mathrm{br}, \mathrm{NH}), 7.3-7.1(\mathrm{~m}, 8 \mathrm{H}, \text { biphenyl ring }), 4.4\left(\mathrm{~m}, 1 \mathrm{H}, \mathrm{CHCH}_{2} \mathrm{CH}_{2}\right), 4.2(\mathrm{q}, \\
\left.2 \mathrm{H}, \mathrm{OCH}_{2} \mathrm{CH}_{3}\right), 3.8\left(\mathrm{q}, 1 \mathrm{H}, \mathrm{CH}\left(\mathrm{CH}_{3}\right) \mathrm{C}(=\mathrm{O}) \mathrm{N}, 2.3\left(\mathrm{t}, 2 \mathrm{H}, \mathrm{CHCH}_{2} \mathrm{CH}_{2}\right), 2.0\right. \\
\left(\mathrm{m}, 2 \mathrm{H}, \mathrm{CHCH}_{2}\right), 1.5\left(\mathrm{~d}, 3 \mathrm{H}, \mathrm{CH}\left(\mathrm{CH}_{3}\right) \mathrm{C}(=\mathrm{O}) \mathrm{N}\right), 1.1\left(\mathrm{t}, 3 \mathrm{H}, \mathrm{OCH}_{2} \mathrm{CH}_{3}\right) .\end{array}$ & 430 \\
\hline
\end{tabular}

Table 4. Percentage protein binding and partition coefficient of synthesized prodrugs

\begin{tabular}{|c|c|c|c|c|c|c|c|}
\hline \multirow{2}{*}{ S. No. } & \multirow{2}{*}{ Prod. Code } & \multirow{2}{*}{$\begin{array}{l}\text { Initial amount } \\
\text { of prodrug / } \\
\text { (mg) }\end{array}$} & \multirow{2}{*}{$\begin{array}{c}\text { Amount of } \\
\text { prodrug bound / } \\
(\mathrm{mg})\end{array}$} & \multirow{2}{*}{$\begin{array}{c}\text { Amount of } \\
\text { prodrug } \\
\text { unbound / }(\mathrm{mg})\end{array}$} & \multirow{2}{*}{$\begin{array}{c}\% \text { Protein } \\
\text { Binding }\end{array}$} & \multicolumn{2}{|c|}{ Partition coefficient } \\
\hline & & & & & & A & $\mathrm{B}$ \\
\hline 1 & AR-1 & 20 & 12.06 & 7.94 & 60.3 & 340.2 & 23.27 \\
\hline 2 & AR-2 & 20 & 8.00 & 12 & 40.0 & 403.85 & 26.32 \\
\hline 3 & AR-3 & 20 & 4.84 & 15.14 & 24.3 & 357.4 & 24.12 \\
\hline 4 & AR-4 & 20 & 11.50 & 8.42 & 57.9 & 688.6 & 36.87 \\
\hline 5 & AR-5 & 20 & 10.02 & 9.98 & 50.1 & 924.9 & 43.05 \\
\hline 6 & AR-6 & 20 & 11.12 & 8.88 & 55.6 & 587.2 & 34.50 \\
\hline 7 & AR-7 & 20 & 6.11 & 13.9 & 30.5 & 1029.9 & 45.29 \\
\hline 8 & AR-8 & 20 & 11.96 & 8.04 & 59.8 & 1040.6 & 45.51 \\
\hline 9 & AR-9 & 20 & 12.92 & 7.00 & 64.6 & 453.5 & 28.49 \\
\hline 10 & AR-10 & 20 & 9.44 & 10.56 & 47.2 & 410.5 & 26.62 \\
\hline
\end{tabular}

A - Partition Coefficient between Chloroform and SGF (pH 1.2); B - Partition Coefficient between Chloroform and Phosphate Buffer Saline (pH 7.4) 
were found 34.50 and 36.87 , respectively and $\mathrm{K}$ value of AR-5, AR-7 and AR-4 were found 43 to 46. The partition coefficient of standard drug FB was 75.62. The partition coefficients of FB prodrugs AR-1, AR-2, AR-3, AR-9 and AR-10 were found between 340 and 454 and partition coefficients of AR-4, AR-5, AR-6, AR-7 and AR- 8 were found between 587 and 1041. Partition coefficient study of prodrugs showed that the major fraction of the prodrugs was partitioned towards the organic phase. It indicates enhancement in the lipophilic property, which might be favorable to biological absorption.

The dissolution studies showed that prodrugs did not show any dissolution in SGF ( $\mathrm{pH}$ 1.2), which might be useful in minimizing the GIT disturbances, however, this may retard absorption of the prodrugs reverse of postulation of higher absorption due to very high partition coefficients. Prodrugs showed reduced dissolution rate as compared to FB due to enhancement in lipophilicity in SIF ( $\mathrm{pH} 7.4$ ), however, enough to get absorbed easily. The result of dissolution study showed that prodrugs AR-1, AR-2, AR-3, AR-9, and AR-10 dissolved $23.76 \%$ to $21.14 \%$; the dissolution of the prodrugs AR-4, AR-5, AR-6, AR-7 and AR-8 was $18.91 \%$ to $18.48 \%$ in two hours.

Protein binding of FB prodrugs in PBS (7.4) of FB prodrugs AR-2, AR-3 and AR-7 ranged between $20 \%$ to $40 \%$; protein binding of AR-4, AR-5, AR-6, AR-10 and AR-8 ranged between $40 \%$ to $60 \%$ and protein binding in prodrugs of AR-1 and AR-5 was found $60.3 \%$ and $64.6 \%$ respectively. Prodrugs showed comparatively very low protein binding in comparison to standard drug. This will increase availability of the prodrug for hydrolysis in plasma and the required dose will be less.

Hydrolytic studies in PBS (pH 7.4) of the prodrugs showed the $t_{1 / 2}$ values (time required for $50 \%$ hydrolysis) of FB prodrugs, AR-7 and AR-8 were found 201.33 and 181.77 min, respectively; $t_{1 / 2}$ values of AR-2, AR-3, AR-4 and AR-6 were found from 165 to $151 \mathrm{~min}$ and the $t_{1 / 2}$ values of AR-1, AR-5, AR-9 and AR-10 were found from 141 to $128 \mathrm{~min}$. Hydrolytic studies of prodrugs in $80 \%$ human plasma ( $\mathrm{pH}$ 7.4) showed $\mathrm{t}_{1 / 2}$ value of $\mathrm{FB}$ prodrugs AR-3, AR-5, AR-1 and AR-8 were found 66 to $53 \mathrm{~min}$; $\mathrm{t}_{1 / 2}$ values of AR-4, AR-2 and AR-7 were found 50 to $39 \mathrm{~min}$ and prodrugs AR-6, AR-10 and AR-9 showed $t_{1 / 2}$ values 34 to $29 \mathrm{~min}$.

The amount of FB regenerated on hydrolysis after $1 \mathrm{~h}$ (in SIF, pH 7.4) of FB prodrugs AR-10, AR-9 and AR-1 was found from $26.66 \%$ to $23.3 \%$; in prodrugs AR-5 and AR-4 drug regenerated was found $20.62 \%$ and $19.0 \%$, respectively; prodrug AR-2, AR- 6 and AR- 8 showed regeneration from $17.76 \%$ to $8.32 \%$ and amount regenerated in prodrug AR-2 and AR-9 was found $8.09 \%$ and $6.86 \%$, respectively.
These results are better than the hydrolysis studies of ester prodrugs of flurbiprofen reported by Halen et al. ${ }^{15}$

The amount of FB regenerated on hydrolysis after $1 \mathrm{~h}$ (in $80 \%$ human plasma, $\mathrm{pH} 7.4$ ) of FB prodrug, AR-10 was found $61.5 \%$; in prodrug AR-9, AR-6 and AR-7 the amount of regenerated drug was obtained from $56.05 \%$ to $49.11 \%$; the amount of regenerated drug was found from $41.09 \%$ to $37.06 \%$, in prodrug AR-3, AR-4, AR-2 and AR-1and the prodrug AR-5 and AR-8 showed $32.82 \%$ and $31.4 \%$ regeneration of drug. None of prodrugs showed hydrolysis in SGF (pH 1.2). Satisfactory hydrolysis was observed in SIF (pH 7.4) and the regeneration of drug was found from 14 to $63 \%$. All prodrugs showed very encouraging hydrolysis rate in $80 \%$ human plasma ( $\mathrm{pH} \mathrm{7.4)}$ and the regeneration of the active drug was found from 63 to $93 \%$. All prodrugs followed first order kinetics. The hydrolysis studies of the prodrugs in human plasma are well comparable with the hydrolysis studies of prodrugs of flurbiprofen reported by Halen et al. ${ }^{15}$

Remaining prodrugs and regenerated drug were estimated using HPLC method due to proper resolution and simplicity. On contrary spectrophotometric method was not found suitable due to very close $\lambda_{\text {max }}$ of the drug and prodrug as well as due to hindrance produced by the color of SGF and SIF. This method was only used to find whether the hydrolysis was taking place or not in acidic buffer ( $\mathrm{pH}$ 1.2) and in phosphate buffer ( $\mathrm{pH} 7.4)$.

The study was performed on HPLC instrument (Shimadzu liquid chromatograph, LC-10 AT) . The mobile phases acetonitrile: water 70:30 ( $\mathrm{pH}$ adjusted to 2.3 using acetic acid) and acetonitrile : water 50:50 were used for estimation of FB prodrugs. Peak area and retention time were noted at $247 \mathrm{~nm}$ using UV detector (DAD, SPD-M10A with $\mathrm{D}_{2}$ lamp) for $\mathrm{FB}$ prodrugs. Flow rate was maintained at $1.2 \mathrm{~mL} / \mathrm{min}$ at $120-135$ psi pressure.

Standard curve of prodrugs in PBS ( $\mathrm{pH} 7.4)$ were prepared using spectrophotometric method at selective $\lambda_{\text {max }}$. The standard curve of prodrug in SGF ( $\mathrm{pH}$ 1.2) and SIF ( $\mathrm{pH} 7.4$ ) and in $80 \%$ human plasma (pH 7.4) was prepared using HPLC method. All these curves were prepared under similar conditions used in the hydrolysis study.

Pharmacological screening of the synthesized prodrugs was done for anti-inflammatory, analgesic and ulcerogenic activity. In each study male albino rats of either sex weighing (100-200 g) were used. The dose of drug or prodrug was given in form of $1 \% \mathrm{CMC}$ suspension through oral route. In case of prodrugs of $\mathrm{FB}$ the dose administered was equivalent to FB (1.2 mg/Kg of body weight).

The anti-inflammatory activities obtained, 2 to $6 \mathrm{~h}$ after the administration of standard drug FB was found $53 \%$ and $45 \%$. The anti-inflammatory activity of FB prodrugs AR-10, AR-9 was found $40.95 \%$ and $40.63 \%$, respectively; 
AR-2 showed inhibition of $34.98 \%$ and the prodrugs AR-7, AR-1, AR-4, AR-3, AR-6, AR-5 and AR-4 showed inhibition between $31 \%$ to $23 \%$.

The anti-inflammatory activity of FB prodrugs AR-9, AR-10 was found $51.56 \%$ and $49.71 \%$, respectively; inhibition in prodrug AR-2, AR-6, AR-1, AR-3, AR-7 and AR-4 was found from $45 \%$ to $40 \%$ and $38.77 \%$ and $34.8 \%$ inhibition was observed in AR-5 and AR-7, respectively. The anti-inflammatory activity of FB prodrugs is better than the anti-inflammatory activity of FB prodrugs reported by Halen et al. ${ }^{15}$ In their study two of the synthesized prodrugs didn't show any anti-inflammatory activity. Higher percentage of the anti-inflammatory effect observed for the amide derivatives might be the result of either better absorption of the amides from the GI tract resulting in higher bioavailability of the compounds or due to higher selectivity of these derivatives towards the COX-2 enzyme than the parent drug.

The analgesic activity of synthesized prodrugs after $1 \mathrm{~h}$ of administration AR-9 and AR-10 was found $58.7 \%$ and $54.2 \%$; in prodrugs AR-6 and AR-4 analgesic activity were found $44.5 \%$ and $40.6 \%$, respectively and analgesia in prodrugs AR-4, AR-1, AR-7, AR-2, AR-5, AR-3 were found from $36 \%$ to $28 \%$ as compared to analgesic activity of FB. The analgesic activities of synthesized prodrugs after $4 \mathrm{~h}$ were AR-8, AR-5, AR-10, AR-4 and AR-6 was found from $70 \%$ to $56 \%$ and this value was found form $54 \%$ to $46 \%$ in case of AR-2, AR-1, AR-3, AR-7 and AR-5 as compared to analgesic activity of $\mathrm{FB}$ the comparative bar diagram is shown in figure 6. Ulcerogenic Index of the synthesized prodrugs was recorded to observe the extent of gastrointestinal side effects (Figure 7). The ulcerogenic index of standard drug FB was found 23.2.

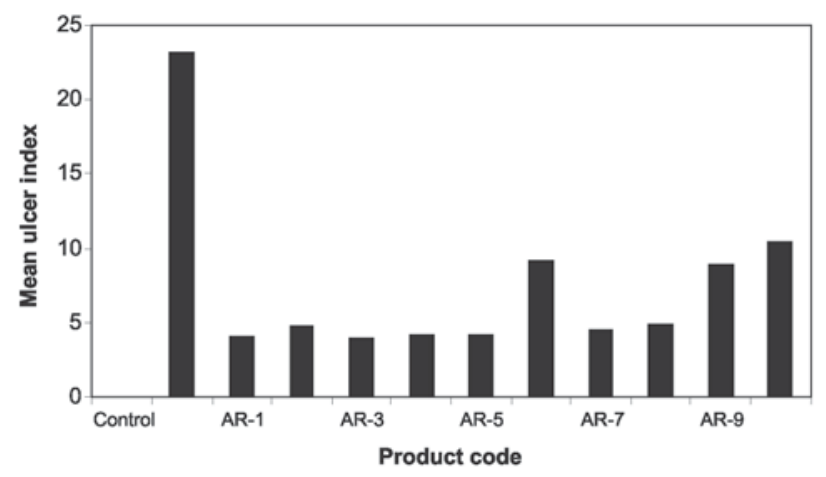

Figure 7. Comparative ulcerogenic indices of amide prodrugs of flurbiprofen.

The ulcerogenic index of prodrugs of Flurbiprofen AR-10, AR-6, AR-9 was found from 10.5 and 8.5; prodrugs AR-8, AR-2, AR-5, AR-4, AR-7, AR-1 and AR-3 showed ulcerogenic index from 4.9 to 3.9. The stability of the prodrugs in buffers of $\mathrm{pH} 2.0$ and 7.4 indicated that the prodrugs would be absorbed intact without exposing the GIT to the acidic carboxy group. Hence, the observed ulcerogenicity of the prodrugs has been attributed to the systemic inhibition of prostaglandins by the parent drug, which was released upon hydrolysis of amides in circulaton.

All the prodrugs showed lesser anti-inflammatory activity in comparison to standard drug in the initial phase, after the administration, but a gradual increase was observed in the activity. After $6 \mathrm{~h}$ of administration, prodrugs showed nearly equal effect in comparison to standard drug. This might be due to various factors including hydrolysis rate, dissolution rate and protein binding etc. Similar pattern of results was obtained in analgesic activity which might be due to same factor involved in the anti-inflammatory activity. Ulcerogenic index of the prodrug was found much lesser in comparison to standard drug. The minimized side effects obtained in the prodrug might be due to inhibition of direct contact of carboxyl group of the drug to the gastric mucosa, which is mainly responsible for the damage. It is also due to negligible dissolution as well as hydrolysis in acidic buffer ( $\mathrm{pH}$ 1.2).

On the basis of the results, it is concluded that prodrug approach can be successfully applied in attaining the goal of minimized gastrointestinal toxicity without loss of desired anti-inflammatory and analgesic activities of the drug. The good pharmacological response indicates that the absorption of the prodrugs might be regulated by some other means like presence of amino acid transport system besides dissolution.

Out of all the synthesized prodrug AR-9, AR-10, AR-2 showed excellent pharmacological response and encouraging hydrolysis rate both in SIF and in $80 \%$ human plasma. On contrary prodrugs with increased aliphatic side chain length or introduction of aromatic substitution showed enhanced partition coefficient but diminished dissolution and hydrolysis rate. Such prodrugs can be considered for sustained release purpose.

\section{References}

1. Vane, J. R.; Botting, R. M.; Inflamm. Res. 1995, 44, 1.

2. Gabriel, S. E.; Jaakkimainen, L.; Bombardier, C.; Ann. Intern. Med. 1991, 115, 787.

3. Roy, S. D.; Manoukian, E.; J. Pharm. Sci. 1994, 83, 1548.

4. Akgun, H.; Tozkoparan, B.; Ertan, M.; Aksu, F.; Inan, S. Y.; Arzneimittel forschung 1996, 46, 891.

5. Doh, H. J.; Cho, W. J.; Yong, C. S.; Choi, H. .; Kim, J. S.; Lee, C. H.; Kim, D. D.; J. Pharm. Sci. 2003, 92, 1008.

6. Tsunematsu, H.; Yoshida, S.; Horie, K.; Yamamoto, M.; Drug Target. 1995, 2, 517. 
7. Mork, N.; Bundgaard, H.; Pharm. Res. 1995, 9, 492.

8. Otagiri, M.; Imai, T.; Fukuhara, A.; J. Control. Release 1999, $62,223$.

9. Banerjee, P. K.; Amidon, G. L.; J. Pharm. Sci. 1981, 70, 1070

10 Mayers, B. E.; Moonka, D. K.; Davis, R. H.; Inflammation 1979, 3, 225.

11. Streitweiser, A. ; Heathcock, G. H.; In Introduction to Organic Chemistry, McMillan Publishing Company: New York, 1989, 947.

12. Norman, R. O. C.; Coxon, J. M.; In Principles of Organic Synthesis, ELBS, Chapman and Hall: London, 1993, 339.
13. Rooseboom, M.; Commandeur, J. N.; Vermeulen, N. P.; Pharmacol.. Rev. 2004, 56, 53.

14. Martin, A. N.; Bustamante, P.; Chine, A. H. C.; Physical Pharmacy, $4^{\text {th }}$ Ed.; B. I.Waverly Pvt. Ltd.: New Delhi, 1993, 212.

15. Halen, P. K. H.; Chagti, K. K.; Giridhar, R; Yadav, M. R.; Helv. Chim. Acta. 2006, 3, 1239.

Received: April 12, 2007

Published on the web: January 28, 2008 